\title{
Simulation and Analysis of Accident Condition and Coping Operations of The Dian Zhong Water Diversion Project
}

\author{
Yibo Yan ${ }^{1, \mathrm{a}}$,Huiyong Huang ${ }^{1}$ Yongyan Wu and Hui Wan ${ }^{1}$ \\ ${ }^{1}$ Changjiang Institute of Survey, Planning, Design and Research, Wuhan, Hubei, China
}

\begin{abstract}
In this paper, according to the characteristics of Dian Zhong Water Diversion Project, as big flow, small cross section, and insufficient escaping capacity, a numerical model of the project is developed. In addition, with analysis, a worst accident condition and operations dealing with it are developed and simulated by the numerical model. With the simulation results, a checking condition is suggested to the structure design.
\end{abstract}

\section{Background}

The Dianzhong region including Dali, Chuxiong, Kunming, Yuxi and Honghe, is the best developed area in economic and society of Yunnan Province, but has been suffering of dramatic lack of water ${ }^{[1]}$.

Dianzhong Water Diversion Project has a canal head of pumping station lifting 3.403 billion cubic metres per year from Jinsha River at Shigu reach, a main line of 664 kilometres long and 635 meters fall head supplying water to Kunming and 4 other cities. As the complex alpine terrain, the project has 118 water conveyance structures in total including 58 tunnels of 611.99 kilometres long, and the bottom slope has a value range of $1 / 1000 \sim 1 / 5000$, this implies the project characteristics of big flow and small cross section ${ }^{[2-3]}$.

As the limited conveyance capacity of passage and to protect the nearby villages, some water release structures has insufficient permissible flow which are far less the design value of the main line. As a result, if some emergency occurs and require to cut off the flow as soon as possible, the water level probably exceed the height of the side wall or even make the free-flow tunnels turn to pressure one. Aiming at these problems, with analysis, a worst accident condition and operations dealing with it is chosen in this paper and a numerical model of the project is developed by which a simulation is made. With the simulation results, the exorbitant water level should be considered as checking condition in structure design.

\section{2 the Worst Condition under Accident}

While operating of Water Transfer Project, kinds of accident such as operational failure, structural damage, water pollution or other unexcepted events, may occur in the main line. In order to reduce the loss and damage scope caused by the accidents, emergency controlling measures (hereinafter referred to as "accident controlling") should be taken to control the deteriorating of the accident.

For some kind of emergency, the upstream accidentcontrol gate at the accident point (the location where the accident occurs) is usually needed to cut off or reduce the flow into the primary section of the accident as quickly as possible. During the closing process of the accident gate, the water level in front of the gate and the upstream part of the channel will be raised, and the pressurized water transfer may be formed in the closed water transfer section, and the overflow of the channel may be caused in the open water transfer section.

In the process of rapid closure of the accident gate, if there is a drainage gate near the upstream, the discharge of the outlet gate can effectively reduce the backwater level. Therefore, in order to reduce the water level backwater caused by cutting off of water flow, the whole main channel is divided by the accident-control gate nearby which there is a drainage gate upstream it.

The canal where the accident occurs is called the primary canal of the accident; for the primary canal of an accident, accident controlling measures such as cutting off water flow will affect the upstream adjacent canal section, which is called the impact section of accident controlling; the upper section of the impact section of accident controlling is called the upstream section of the accident; and the lower section of the primary section of the accident can be named the downstream section of the accident. As shown in Figure 1.

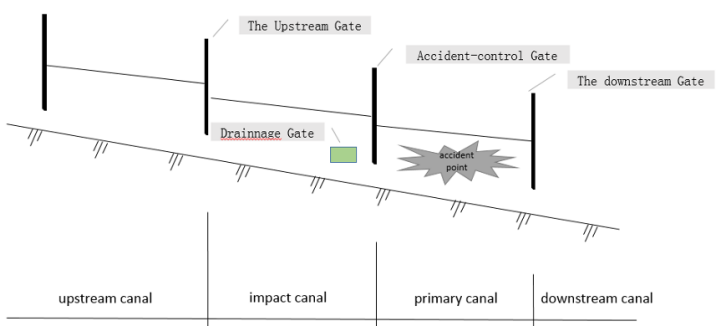

Figure 1 Canals and Gates in Accident Controlling 
The main canal of Dianzhong Water Diversion Project can be divided into 29 accident-control canals. According to the flood analysis of natural drainage channel and the measurement of surrounding farmland houses, the permissible drainage capacity of natural drainage channel was determined. There were 11 accident-control canals with insufficient drainage capacity.

\section{Operating measures Optimization}

Parameters of typical operating measures include: the starting time of the accident-control gate and the drainage gate; duration of the operating of the accidentcontrol gate and the drainage gate; and the target flow rate of the accident-control gate and the drainage gate.

In order to optimize of the operating measures, hydraulic response of operating measures in XiaHeba accident-control canal is simulated with different combination schemes of measure parameters, and the highest backwater level of the XiaHeba accident-control gate is shown in Table-1.

Table 1. The Highest Backwater Level of the XiaHeba

\begin{tabular}{|c|c|c|c|c|c|c|}
\multicolumn{7}{|c}{ Accident-control Gate (M). } \\
\hline \multirow{2}{*}{$\begin{array}{c}\text { accident-control } \\
\text { measures }\end{array}$} & \multicolumn{3}{|c|}{$\begin{array}{c}\text { Duration of XiaHeba Gate closing } \\
\text { (min) }\end{array}$} & \multirow{2}{*}{$\begin{array}{c}\text { Water level } \\
\text { difference }\end{array}$} \\
\cline { 2 - 7 } & $\mathbf{5}$ & $\mathbf{1 5}$ & $\mathbf{3 0}$ & $\mathbf{6 0}$ & \\
\hline $\begin{array}{c}\text { Duration } \\
\text { of drainage } \\
\text { Gate } \\
\text { opening } \\
\text { (min) }\end{array}$ & $\mathbf{1}$ & 1995.3 & 1995.1 & 1994.8 & 1994.4 & 1.33 \\
\cline { 2 - 7 } & $\mathbf{5}$ & 1998.9 & 1995.1 & 1994.9 & 1994.4 & 4.9 \\
\hline $\begin{array}{c}\text { Water level } \\
\text { difference }\end{array}$ & 1998.9 & 1995.2 & 1994.9 & 1994.5 & 4.86 \\
\hline
\end{tabular}

The results show that:

1) With a constant duration of the operating of the accident-control gate, the faster the drainage gate opening, the smaller the backwater level is.

2) When the duration of the operating of the drainage gate is longer than or equal to 5 minutes, the closing speed of the accident-control gate has a limited effect on the backwater level in front of it.

3) With a constant duration of the operating of the drainage gate, the slower the accident-control closing, the smaller the backwater level is

4) When the duration of the operating of the accident-control gate is longer than or equal to 15 minutes, the opening speed of the drainage gate has a limited effect on the backwater level in front of the accident-control gate.

5) On condition of the accident-control gate is closed longer than 5 minutes, if the drainage gate cannot be opened in 1 minute, the water level in front of the accident-control gate and the pressure of the tunnel will increase drastically.

6) If the accident-control gate is closed longer than 30 minutes, a limited rise of water level or pressure of the tunnel can be expected.

In order to establish an exacting checking condition formed by accident coping operations, some reasonable but more unfavourable measure parameters should be chosen. So, on analysis above, the typical accidentcontrol measures as shown in Table 2.

Table 2. The Typical Accident-control Measures

\begin{tabular}{|c|c|c|c|c|c|}
\hline & & $\begin{array}{c}\text { starting } \\
\text { time }\end{array}$ & $\begin{array}{c}\text { ending } \\
\text { time }\end{array}$ & $\begin{array}{c}\text { starting } \\
\text { flow }\end{array}$ & $\begin{array}{c}\text { target } \\
\text { flow }\end{array}$ \\
\hline & & $\min$ & $\min$ & $\mathbf{m}^{3} / \mathbf{s}$ & $\mathbf{m}^{3} / \mathbf{s}$ \\
\hline \multirow{3}{*}{$\begin{array}{l}\text { The } \\
\text { impact } \\
\text { canal }\end{array}$} & $\begin{array}{l}\text { the upper } \\
\text { gate }\end{array}$ & 0 & 15 & $\begin{array}{c}\text { Design } \\
\text { value }\end{array}$ & 0 \\
\hline & $\begin{array}{c}\text { drainage } \\
\text { gate }\end{array}$ & 0 & 5 & 0 & $\begin{array}{c}\text { Design } \\
\text { value }\end{array}$ \\
\hline & $\begin{array}{l}\text { Accident- } \\
\text { control } \\
\text { gate }\end{array}$ & 0 & 15 & $\begin{array}{c}\text { Design } \\
\text { value }\end{array}$ & 0 \\
\hline
\end{tabular}

\section{Simulation Methods and Algorithm}

\subsection{Initial Condition}

Initial conditions refer to the occurrence of an accident, the imminent start of the accident control time, water level distribution along the water source pumping station, main canal, sectional flow, flow of outlet gate. Accidents may occur at any time and the initial state varies greatly. The actual control should be analysed according to the specific situation. However, when the main canal is operating the design flow, there will be the initial condition of large fluctuation of water level. Considering safety, the initial conditions of the main canal for accident scheduling are as follows:

1) the water pumping station is stable water pumping as design flow of $135 \mathrm{~m} 3 / \mathrm{s}$.

2) The flow pattern along the main canal is constant, the water level is the section al design level, and the discharge is the design flow of the section.

3) All working sluice gates along the line are opened and drainage gates are closed, flow-limiting gates in accident and accident-control gates are opened, and outlet gates are opened according to the water supply plan.

\subsection{Boundary Condition}

In the hydraulic calculation of accident control, the geometric boundary conditions of the main canal are determined by the preliminary design stage, the plane layout of the control structures and the vertical and transverse sections, and the channel roughness is determined by the design value.

\subsection{Simulation Algorithm}

The unsteady open channel flow in the aqueduct, culvert and tunnel of Dianzhong Water Diversion Project is simulated by Saint-Venant equation set.

The head of inverted siphon in main canal of Dianzhong Water Diversion Project is mostly below $15 \mathrm{~m}$ and belongs to low pressure building. At the same time, the internal flow velocity of inverted siphon is generally only $2-3 \mathrm{~m} / \mathrm{s}$, and the control gate is usually arranged in the open gate chamber of inverted siphon outlet. When the gate is closed, no obvious water hammer will be produced, which is a low-pressure pipe flow. The constitutive equation of the low-pressure pipe 
flow is the same as that of the open channel flow, so the unsteady flow of the low-pressure pipe flow can be calculated by the same algorithm of the Saint-Venant equation $\operatorname{set}^{[4]}$.

\section{Simulation Results}

Through hydraulics calculation of unsteady flow, in the process of emergency control, the water level in front of the accident-control gate will be significantly raised. When the accident gate is closed, the channel with insufficient water withdrawal capacity will be filled with water because the inflow is greater than the outflow, resulting in the tunnel turning from no pressure to pressure, as shown in the figure 2 .

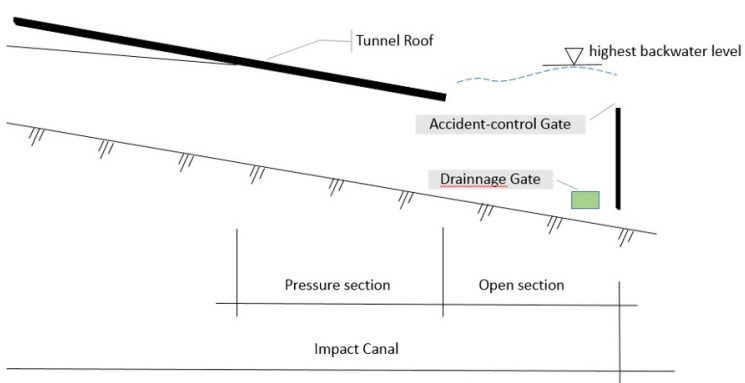

Figure 2. Hydraulic Response with Operating Measures

Through the simulation calculation, the possible hydraulic effects on each section of Dianzhong Water Diversion Project main line under accident conditions are shown in Table 3- Table 7.

Table 3 Hydraulic Response of Operating Measures of

\begin{tabular}{|c|c|c|c|c|}
\hline $\begin{array}{c}\text { No } \\
\text {. }\end{array}$ & $\begin{array}{c}\text { Constructio } \\
\text { n name }\end{array}$ & $\begin{array}{c}\text { Water } \\
\text { level } \\
\text { beyond } \\
\text { design } \\
\text { value }\end{array}$ & $\begin{array}{c}\text { The } \\
\text { highest } \\
\text { pressure } \\
\text { in tunnel }\end{array}$ & $\begin{array}{c}\text { Length of } \\
\text { pressure } \\
\text { section }\end{array}$ \\
\hline \multirow{2}{*}{2} & Tunnel 2 & - & 2.19 & 9177 \\
\hline & Gate 2 & 4.43 & - & - \\
\hline \multirow{2}{*}{3} & Tunnel 3 & - & 0.50 & 2121 \\
\hline & Gate 3 & 2.67 & - & - \\
\hline
\end{tabular}

Table 4 Hydraulic Response of Operating Measures of Dali-II (m)

\begin{tabular}{|c|c|c|c|c|}
\hline \multirow{2}{*}{ No. } & $\begin{array}{c}\text { Construc } \\
\text { tion } \\
\text { name }\end{array}$ & $\begin{array}{c}\text { Water level } \\
\text { beyond } \\
\text { design } \\
\text { value }\end{array}$ & $\begin{array}{c}\text { The } \\
\text { highest } \\
\text { pressure in } \\
\text { tunnel }\end{array}$ & $\begin{array}{c}\text { Length of } \\
\text { pressure } \\
\text { section }\end{array}$ \\
\hline \multirow{2}{*}{5} & Tunnel 5 & - & 3.58 & 15036 \\
\cline { 2 - 5 } & Gate 5 & 5.94 & - & - \\
\hline \multirow{2}{*}{6} & Tunnel 6 & - & 5.28 & 22176 \\
\cline { 2 - 5 } & Gate 6 & 7.66 & - & - \\
\hline \multirow{2}{*}{8} & Tunnel 8 & - & 4.40 & 11602 \\
\cline { 2 - 5 } & Gate 8 & 6.55 & - & - \\
\hline
\end{tabular}

Table 5 Hydraulic Response of Operating Measures of Chu Xiong $(\mathrm{m})$

\begin{tabular}{|c|c|c|c|c|}
\hline No. & $\begin{array}{c}\text { Construc } \\
\text { tion } \\
\text { name }\end{array}$ & $\begin{array}{c}\text { Water level } \\
\text { beyond } \\
\text { design }\end{array}$ & $\begin{array}{c}\text { The highest } \\
\text { pressure in } \\
\text { tunnel }\end{array}$ & $\begin{array}{c}\text { Length of } \\
\text { pressure } \\
\text { section }\end{array}$ \\
\hline
\end{tabular}

\begin{tabular}{|c|c|c|c|c|}
\hline & & value & & \\
\hline 10 & Gate 10 & 1.44 & - & - \\
\hline 14 & Gate 14 & 0.46 & - & - \\
\hline
\end{tabular}

Table 6 Hydraulic Response of Operating Measures of Kun Ming (m)

\begin{tabular}{|c|c|c|c|c|}
\hline \multirow{2}{*}{ No. } & $\begin{array}{c}\text { Construc } \\
\text { tion } \\
\text { name }\end{array}$ & $\begin{array}{c}\text { Water level } \\
\text { beyond } \\
\text { design } \\
\text { value }\end{array}$ & $\begin{array}{c}\text { The } \\
\text { highest } \\
\text { pressure } \\
\text { in tunnel }\end{array}$ & $\begin{array}{c}\text { Length of } \\
\text { pressure } \\
\text { section }\end{array}$ \\
\hline \multirow{2}{*}{21} & Tunnel 21 & - & 3.4 & 3382 \\
\cline { 2 - 6 } & Gate 21 & 4.36 & - & - \\
\hline
\end{tabular}

Table 7 Hydraulic Response of Operating Measures of

\begin{tabular}{|c|c|c|c|c|}
\hline \multirow{2}{*}{ No. } & $\begin{array}{c}\text { Construc } \\
\text { tion } \\
\text { name }\end{array}$ & $\begin{array}{c}\text { Water level } \\
\text { beyond } \\
\text { design } \\
\text { value }\end{array}$ & $\begin{array}{c}\text { The } \\
\text { highest } \\
\text { pressure in } \\
\text { tunnel }\end{array}$ & $\begin{array}{c}\text { Length of } \\
\text { pressure } \\
\text { section }\end{array}$ \\
\hline \multirow{2}{*}{24} & $\begin{array}{c}\text { Tunnel } \\
24\end{array}$ & - & 0.81 & 807 \\
\cline { 2 - 5 } & Gate 24 & 1.75 & - & - \\
\hline \multirow{2}{*}{28} & $\begin{array}{c}\text { Tunnel } \\
28\end{array}$ & - & 1.76 & 1759 \\
\cline { 2 - 5 } & Gate 28 & 2.70 & - & - \\
\hline
\end{tabular}

\section{Conclusion}

For long-distance water diversion projects crossing mountainous and hilly areas, the most unfavorable accident conditions should be analyzed and determined, and the design results of the buildings should be checked according to the results of hydraulic simulation. By which, the measures such as increasing the capacity of water diversion channel, increasing the height of side wall of open flow section, and lining of tunnel should be compared and selected to ensure the structure of water conveyance structures's safe.

The main line of Dianzhong Water Diversion Project can be divided to 29 accident-control canals o, 11 of which are with insufficient water withdrawal capacity. Under typical accident controlling conditions, pressure sections occur in 9 tunnels, and the maximum pressure head at the top of the tunnel pressure section is $5.28 \mathrm{~m}$, which has a pressure section of $22176 \mathrm{~m}$ long.

\section{Acknowledgment}

This paper was supported by the National Key Research and Development Program of China (Grant No.2016YFC0401810), Independent research project of C.I.S.P.D.R. (CX2017Z03)

\section{Reference}

1. The ASCE task committee on Irrigation Canal System Hydraulic Modeling. Unsteady-flow Modeling of Irrigation Canals $[\mathrm{J}]$. Journal of 
Irrigation and Drainage Engineering, ASCE, 1993,119(4):615-630.

2. Clemmens, A. J., Strelkoff, T. S., Replogle J. A. Calibration of Submerged Radial Gates[J]. Journal of Hydraulic Engineering, ASCE ,2003, 129(9): 680687.

3. Reddy, J M Design of global control algorithm for irrigation canals[J]Journal of hydraulic engineering 1996, (9):503-511

4. E Bautista, Volume compensation method for routing irrigation canal demand changes $[\mathrm{J}]$ Journal of Irrigation and Drainage Engineering, 2005, (6131):494-503. 